\title{
Choosing a Smuggler: Decision-making Amongst Migrants Smuggled to Europe
}

\section{Paolo Campana ${ }^{1}$ (D) Loraine Gelsthorpe $^{1}$}

Published online: 27 July 2020

(C) The Author(s) 2020

\begin{abstract}
This paper explores how transactions between smugglers and migrants come about in the context of irregular migration. We first offer some theoretical reflections on the challenges that such a context poses to both parties - smugglers and migrants - and point to three main conditions under which smuggling transactions take place: illegality, asymmetrical information and low trust. Next, we explore the strategies that migrants and smugglers alike may employ to overcome these challenges. We focus on three broad sets of strategies related to information-gathering, to information-checking (reputation and the role of physical and virtual communities) and to developing substitutes for trust (guarantees, escrow services and hostage-taking strategies à la Thomas Schelling). To illustrate our reasoning, we draw on examples from published works as well as from a novel set of 43 qualitative interviews with migrants recently smuggled to Europe. Such interviews were carried out in a destination country (England) and in a transit country (Greece). Evidence from this work supports previous calls to move away from a simplistic "predator-victim" discourse.
\end{abstract}

Keywords Migrant smuggling $\cdot$ Decision-making $\cdot$ Trust $\cdot$ Information $\cdot$ Reputation

\section{Introduction}

In the 5-year period 2014-2018, a combined $1.86 \mathrm{~m}$ illegal border crossings (IBCs) have been recorded at the Greek and Italian borders (Frontex 2017, 2019). ${ }^{1}$ A roughly similar number of IBCs have been detected by US law enforcement authorities at the Mexico-US border between

\footnotetext{
${ }^{1}$ The data from Frontex also include Malta; however, the number of illegal border crossings attributable to Malta is very limited (see also Campana 2017).

Paolo Campana

pc524@cam.ac.uk

1 Institute of Criminology, University of Cambridge, Sidgwick Avenue, Cambridge CB3 9DA, UK
} 
2013 and 2017 (1.94 m; DHS 2019: 121). Based on interviews with apprehended migrants, US Border Patrol have estimated a smuggler "usage rage" of between 80 and $95 \%$ in 2015. Data from the Mexican Migration Project at Princeton University suggest a similar level of smuggler involvement — close to 90\% in 2017 (Sanchez 2018a: 153). Moreover, in 2018, the EU Border and Coast Guard Agency (Frontex) conducted voluntary interviews with newly arrived migrants in Italy, Greece and Spain: $84 \%$ of the migrants interviewed claimed that they used a smuggler while only $7 \%$ stated that they had not (9\% did not reply to the question; alas, the total number of interviews was undisclosed but the findings are nevertheless interesting: Frontex 2019: 28). Enlisting the services of a smuggler is not without its challenges: first, one needs to identify potential smugglers and then one needs to check their credentials, make a judgement about their trustworthiness and - ultimately - make a decision over whether to entrust one's life to a specific smuggler or not. These are not easy decisions. Yet data from both Europe and the USA show that large volumes of transactions between migrants and smugglers have indeed taken place. How do people make such decisions in the context of migration outside state-sanctioned channels?

In this paper, we explore how these transactions have come about in a context characterised by challenging conditions: severe risks, low trust and asymmetry of the information available. We consider both smugglers and migrants as rational actors who seek to choose the best option compared to the alternatives available (Elster 1989). As put it by Elster (1989: 20), when "faced with several courses of action, people usually do what they believe it is likely to have the best overall outcome". Interviews with migrants carried out as part of this study confirmed that people had a set of alternatives available to them when choosing a smuggler, and they had to make difficult decisions as to what option to pick, bearing in mind the constraints on selection by virtue of their migrant status. We follow Elster (1989: 13) in seeing social actions as the end result of a two-stage process: first, all abstractly possible actions that an individual might undertake are filtered by physical, economic and sociological constraints; second, an action is carried out within the resulting opportunity set. In this paper, we focus on the second stage of this process.

Our approach challenges the "binary predator-victim position that saturates the official discourse on illegal migration" (Zhang, Sanchez and Achilli 2018: 8) and offers a more nuanced perspective on human smuggling (in line with Doomernik and Kyle 2004; Zhang 2007; Sanchez 2015; Achilli 2018; Sanchez and Zhang 2018). As Zhang, Sanchez and Achilli (2018: 8) point out, "the binary predator-victim perspective rarely applies in a context where both migrants and smugglers actively engage in negotiating, vetting and trading". Let us reiterate that this does not imply that migrants face matters without risks, nor that the relationship between smuggler and migrant is symmetrical - quite the opposite. Yet, strategies to decrease risk and overcome the challenges posed by the context of irregular migration have been developed by both smugglers and migrants.

\section{Purpose of the Paper}

The aim of this paper is to explore both the challenges related to transactions in the context of human smuggling and the strategies developed to overcome these challenges. In this paper, we offer some theoretical reflections on how the choice of a smuggler might come about and discuss the decision-making process underpinning such difficult and consequential decisions.

This paper proceeds as follows: the next section introduces the methodology underpinning the work, including a discussion of the research design and the methods of data analysis. The 
following section discusses the problems related to transacting under conditions of illegality, asymmetrical information and low trust. Next, the paper looks at the strategies that migrantsand smugglers alike - might employ to address these problems: information-gathering ("Gathering Information"), information-checking ("Judging a Smuggler's Trustworthiness") and substitutes for trust ("Substitutes for Trust: Guarantees, Escrow Services And Hostage-Taking"). The "Conclusions" section concludes.

\section{Methodology: Research Design, Methods and Ethical Considerations}

To illustrate our reasoning, we draw examples from published works as well as from a novel body of evidence derived from 43 qualitative interviews with migrants recently smuggled to Europe. Such interviews were collected during a fieldwork that encompassed both a destination country (England) and a transit country (Greece). We carried out two sets of interviews.

The first set consists of 19 semi-structured in-depth interviews with Arabic-speaking refugees carried out in various cities in England in July and August 2016. Interviews were conducted in Arabic by a native speaker and then translated into English by the same person. These interviews are quoted in the text using an ID from 1 to 19 . The second set consists of 24 informal interviews conducted during two field visits to Greece. These interviews are quoted in the text using an ID from 20 to 43. This set of informal interviews was carried out in four settings: Athens, Idomeni and two refugee camps in the Thessaloniki area. A translator assisted during the interviews. The field visits took place in March-April 2016 and August 2016. In both cases, the interviewees were identified using a snowball sampling technique.

Access to participants was facilitated by contacts with volunteers and non-government organisations (NGOs) assisting migrants in, respectively, England and Greece. In total, there were interviews with 43 migrants: 33 males and 10 females. With regard to their declared nationality, interviewees were predominantly Syrian (34): two were Iranian, two Iraqi, two Sudanese, one Moroccan, one Kuwaiti and one Turkish (Kurdish).

In order to analyse the data, all the interviews were transcribed and merged into a single text file. Secondly, we conducted a thematic content analysis of the interviews based on the broad themes discussed in the paper (e.g. "trust", "cheating", "information-gathering", "informationchecking"). Within each theme, we then coded sub-categories as they emerged from the content of the interviews. While the first step has been mostly top-down, in the second, we have let the evidence speak for itself as much as possible (on content analysis, see Krippendorff 2004).

Consent was given for the interviews, although not all the participants wished to give indication of their consent in writing (for obvious reasons regarding their status). In these cases, consent was recorded orally.

\section{Challenges of Transacting in the Context of Irregular Migration}

This paper interprets human smuggling as a form of illegal trade in which the commodity traded is primarily the illegal entry into a country - in line with Bilger et al. (2006), Kleemans (2011) and Campana and Varese (2016). This sets smuggling apart from human trafficking, as in the latter case, the commodity traded is primarily control over a person (see Campana and Varese 2016 for a theoretical discussion, and Hales and Gelsthorpe 2012 for experiences of 
trafficked women). By definition, trade takes place in a market, which in turn is characterised by supply and demand. In this specific instance, migrants constitute the demand-side of the market: they are willing to buy a service, i.e. illegal entry into a country, for a variety of reasons that include leaving war zones, escaping poverty, avoiding persecution or looking for a better life (see, among others, Robinson and Segrott 2002; Antonopoulos and Winterdyk 2006; Yildiz 2017, Optimity Advisors and Seefar 2017: 15 for a discussion of the motivations to migrate). The demand for smuggling services is satisfied by a number of sellers. In this specific market, they are collectively defined as smugglers. When framed in this way, smuggling is the outcome of a successful transaction, i.e. an agreement between a smuggler and a migrant. The context in which these transactions take place is challenging due to a number of conditions. In this paper, we focus on three such conditions: illegality, asymmetrical information and low trust.

\section{Decisions Under Condition of Illegality}

Following the UN Protocol against the Smuggling of Migrants (UN 2000), which has now been signed by 112 states, the smuggling of migrants is considered a criminal offence "when committed intentionally and in order to obtain, directly or indirectly, a financial or other material benefit" (Article 6). Due to its condition of illegality, the market for smuggling services is characterised by the absence of formal enforcement mechanisms to solve disputes, ensure compliance and enforce contracts (Reuter 1983: Ch. 5; Campana and Varese 2013). In addition, transactions may be hindered by the mobility of illegal actors as well as by the difficulties in creating a credit market to sustain them (Reuter 1983 and 1985; Campana and Varese 2013). Furthermore, illegality has a direct impact on the availability and quality of information available. Sellers may find it very difficult and costly to freely advertise their products and their reputation (Reuter 1983; Gambetta 2009; Campana and Varese 2013). Buyers, on the other hand, may find it difficult to collect reliable information about the quality of goods and services given the absence of reputable independent sources (Campana and Varese 2013). There is evidence that a higher level of enforcement increases the need to enlist the service a smuggler (Massey et al. 2016: 1590). At the same time, a higher level of enforcement exacerbates the challenges faced when enlisting such smugglers.

\section{Decisions Under Condition of Asymmetrical Information}

In 1970, economist George Akerlof explored the problem of quality uncertainty in his seminal paper on the market for lemons ("lemon" is an American slang word to describe a highlyflawed item, in the case of Akerlof a poor second-hand car). In Akerlof's model, the secondhand car market is populated by two types of goods: good quality cars and bad quality cars ("lemons"). Sellers have more knowledge about the quality of a given car than the buyers, and it is very difficult for the latter to tell the difference between a good car and a bad car. This puts the buyer in a difficult position, as she knows that some cars are indeed of low quality, but she is not able to sort them from the good quality ones. Sellers of good quality cars are also affected as they suffer from the (unfair) competition from the sellers of bad cars, and, as a result, they may have to accept a lower price or exit the market altogether. In Akerlof's example, the market is characterised by a problem of asymmetrical information between buyers and sellers, and this problem - if left unaddressed - is predicted to lead to the collapse of the market itself (Akerlof 1970: 490-492). 
Arguably, the same problem is present in the case of human smuggling: smugglers hold more information about the quality of their services than their potential clients, and the latter have to make decisions with imperfect information and under conditions of uncertainty (Bilger et al. 2006). If the smugglers were all equally callous and sellers of lemons, then information asymmetries would be irrelevant. However, evidence from different studies shows that there is variation among smugglers in the "level" of service they provide. Ayalew Mengiste (2018: 70-71) presents testimonies of Eritreans migrants who portrayed their smugglers' actions in positive terms. Based on his fieldwork with Syrian migrants, Achilli (2018: 83) similarly recalls that "accounts about the callousness of smugglers were often dismissed by those very people who risked their life crossing the Mediterranean. The majority of migrants with whom I spoke did not perceive their smugglers as exploitative". Sanchez (2018: 35) presents first-hand stories of women smuggled on the Mexico-US route and maintains that many of her interviewees shared "stories of supporting male and female smuggling facilitators during their transit" (see also Sanchez 2015, Chapter 4). Based on her fieldwork on the island of Lesbos, Siegel (2019) writes that "human smugglers [...] were not considered as criminals, at least not by the migrants who had been smuggled. On the contrary, the smugglers were seen as important helpers".

Some of our interviewees equally felt protected by the smuggler while en route: "Yes, there was [protection]. For example, if someone tried to take something from me, the smuggler would stop the person" (interview 6; also interviews 15 and 16). Maher (2018) expresses a similar view about protection in relation to smuggling from West Africa.

Yet cheaters and unscrupulous smugglers do exist. For example, Spener (2009) documents instances of individuals posing as smugglers in bus terminals and areas around the international bridges in Mexican border towns in order to swindle migrants or lead them to isolated places and then assault and rob them (Spener 2009: 155; also Slack and Martínez 2018: 153). In a (rare) quantitative survey carried with migrants who had enlisted the services of smugglers to cross from Mexico into the USA, 75\% of the 655 interviewees declared that they were satisfied with the service provided by their smuggler (Slack and Martínez 2018: 162). However, only $45 \%$ would recommend their smuggler to a family member or a friend (even among those who were satisfied, only slightly more than half would recommend their smuggler: 57\%; Slack and Martínez 2018: 162). As one of our interviewees put it, "there are a lot of smugglers... good and bad, those who steal [and those who don't]" (interview 11).

The evidence from different routes points to the existence of both "good" and "bad" smugglers in a similar fashion to the situation described by Akerlof (1970). However, compared to the market analysed by Akerlof, the consequences of a bad choice can be much more severe in the case of human smuggling, as they can include physical abuse and the loss of life. For instance, $3 \%$ of the migrants surveyed at the US-Mexico border experienced abuse by a group member and 6\% witnessed abuse by a group member (Slack and Martínez 2018: 162, $N=655$ ). According to the figures from the Missing Migrant Project database compiled by IOM, the number of deaths recorded at the US-Mexico border was at least 2336 for the period 2014-2019 with a yearly average of 389 fatalities. The figures for the Mediterranean route are even starker: 14 migrants are estimated to have lost their life per 1000 people safely crossing in 2018 and 7 per 1000 in 2019.

While migrants face the most severe risks, uncertainty also affects smugglers. For instance, migrants might refuse to pay a smuggler, or just disappear, after a service has been rendered, or they can report the whereabouts of a smuggler to the authorities (Ayalew Mengiste 2018: 6667 offers some evidence on this point in the context of Eritrean smuggling). Akerlof (1970: 
499-500) identified a number of mechanisms that market players can resort to in order to sustain transactions. These include offering guarantees and developing brand names or relying on a licensing system developed by a third party. We discuss these mechanisms in the context of human smuggling in the remainder of the paper.

\section{Decisions Under Scarcity of Trust}

Information asymmetries would not matter that much if the smuggling market was characterized by a high level of trust. Several authors have pointed to the importance of trust in supporting transactions in legal settings (Gambetta 1988; Coleman 1990; Yamagishi and Yamagishi 1994; Hardin 2006) as well as illegal ones (McCarthy et al. 1998; Campana and Varese 2013). The importance of trust has been highlighted by several scholars also in the context of human smuggling and regardless of the route under consideration. Spener (2004), Kyle and Scarcelli (2009) and Sanchez et al. (2018) have looked at various routes in the USA while Bilger et al. (2006), Triandafyllidou and Maroukis (2012), Campana and Varese (2016) and Achilli (2018) have considered various routes into Europe: they all come to the same conclusion (Zhang et al. 2018 offer an over-arching view). Migrants themselves have cited trustworthiness as one of the key quality they value in smugglers (Slack and Martínez 2018: 152). This is little disagreement that trust is important. However, building it is not an easy task. This is particularly true in the context of human smuggling where a number of factors that might hinder such creation.

One key factor is the constant risk of being cheated, that is, provided with a service of a lower quality than promised or provided with no service at all. This is indeed a risk that migrants we interviewed perceive as concrete. There are a number of ways in which migrants may fall victim to cheating. Outright fraud constitutes a classic example. One of our interviewees witnessed an entire family paying 11,000 USD to a smuggler who then immediately disappeared after claiming that he was going to get a taxi for them (interview 17). A similar story was related to us by another interviewee (interview 16). In other cases, dishonest actors would claim not to be able to accept the local currency, for example Libyan dinars, and offering instead to exchange the migrant's money into Euros or US dollars only to disappear (interview 5).

The belief that one person may conceivably end up being cheated ultimately erodes collective trust. The majority of the migrants we interviewed were rather upfront about their (low) expectations with regard to the trustworthiness of smugglers. The picture that emerges is one in which smugglers tend to be collectively perceived as untrustworthy. ${ }^{2}$ Migrants seem to have entered the smuggling process with relatively low expectations among the level of collective trust present in the smuggling market. While we do not possess survey data that directly measure such level, our limited evidence suggests that trust is likely to be in short supply. Yet, transactions do take place as is testified by the fact that all our respondents had ultimately made an agreement with a smuggler and successfully entered the European Union.

If generalised trust is on the lower end of the spectrum, we can expect two separate strategies to be adopted by migrants and smugglers, respectively. Migrants need to develop strategies to sort the more trustworthy smugglers from less trustworthy ones. On the other

\footnotetext{
${ }^{2}$ It should be noted here that all our interviews were conducted in Europe, therefore after the riskiest part of the smuggling experience. Further work is needed to measure the level of trust before entering the smuggling process.
} 
hand, trustworthy smugglers - the "good" smugglers as Achilli (2018) puts it - need to develop strategies to distinguish themselves from the less trustworthy competitors. We now turn to explore some of these strategies in more detail.

\section{Gathering Information}

In choosing a smuggler, migrants first need to collect information about the available counterparts and the type and quality of the services offered. Information-gathering is a key stage in one's decision-making process (Elster 1989). Its importance is reflected in the words of one interviewee: "I took three months to research because if someone screwed me over, I would be in trouble. I would be finished and die in the desert. I wouldn't have anything else if they had stolen from me." (interview 11). Van Liempt and Doomernik (2006: 176) collected and analysed the life stories of 68 migrants who entered the Netherlands irregularly and pointed out "how careful migrants are in deciding with whom to migrate". As noted by Sanchez et al. (2018: 18) in the context of sea crossings from Libya into Italy, "decisions concerning travel with smugglers were typically not improvised". Ethnographic work with Anglophone Cameroonians carried by Alpes (2012) points to a similar conclusion.

Personal contacts remain a major source of information. Among our interviewees, the "word-of-mouth" approach, mostly through family and friends, still appears to be the principal strategy to collect information (interview 7; interview 10; interview 11; interview 17). The reliance on personal contacts in the context of migration has been widely documented (see, among others, Herman 2006). Irregular migration is no exception. Van Liempt and Doomernik (2006: 174) pointed out that "[m]ost of the respondents had met their first smuggler through family members, friends, or acquaintances". In a survey with 686 migrants who have crossed from Libya into Italy, Sanchez et al. (2018: 26) found that $74 \%$ of the respondents had used personal contacts to get in touch with their most trusted source of information (also Optimity Advisors and Seefar 2017: 41). On the Mexico-US route, $53 \%$ of the 655 migrants surveyed in Slack and Martinez's sample (2018: 162) made contact with the smuggler through someone they knew. Migrants who successfully arrived at their destination are often a valuable source of information, as highlighted by one of our interviewee (interview 15).

Sometimes it is the smugglers themselves that pro-actively convey information about their activity. Several interviewees have highlighted the entrepreneurialism of smugglers in their active search for clients: "There are buses and you don't know who is a smuggler but they say, "sir we will get you to the border of Libya if you give us 400 dollars" (interview 2). Another interviewee was approached by a person and told: "I have this passport that looks like you and can smuggle you out but you need to remove your beard and hair." (interview 15).

Not all the decisions can be made prior to departure. Migrants might find themselves in a position of having to choose new smugglers while en route. This is often the consequence of the smuggling operations being fragmented and run by localised groups (Zhang and Chin 2002; Içduygu and Toktas 2002; Campana 2018, 2020). Smuggling hubs can then play an important role for the dissemination of information. Such hubs are often an "open secret" (see, among others, van Liempt and Doomernik 2006; Spener 2009; Achilli 2018). Evidence from our fieldwork also supports this view (interview 7; interview 9; interview 10; interview 17). Our interviewees mentioned particular squares or neighbourhoods, often lined with cafes or market stalls, where smugglers could be 
found. In some cases, transport hubs double as smuggling hubs. What is interesting about smuggling hubs is that they not only fluidify the meeting of demand and supply by allowing a better-and more targeted - circulation of information, but they also provide an infrastructure (e.g. cafes) to facilitate face-to-face meetings. As we will discuss in the next section, this is a crucial step in checking a smuggler's credentials. Refugee camps are, perhaps not unexpectedly, among such hubs: "the smuggler was living with the people in the camp and everyone knew him. Everyone knew he was a smuggler, that he was Kurdish and what his name was". (Interview 16).

With the evolution of information technology, migrants and smugglers alike have started to turn to online sources, particularly social media. The latter provides a platform for migrants to gather information beyond the traditional boundaries of their acquaintances or physical hubs. While not replacing word of mouth, social media appears to play an increasingly important role. A handful of interviewees have indicated that they have accessed Facebook to gather information about smugglers (interview 11; interview 13; interview 17). One interviewee has indicated the presence of "well-know groups" on Facebook where users "write that they arrived and you can talk to them and ask them the questions like how did you arrive, with which smuggler, they give you his phone number etc. I did a lot of research and talked to a lot of people" (interview 11). The findings by Dekker et al. (2018) go in the same direction: of the 51 Syrian refugees they have interviewed in the Netherlands, $80 \%$ had consulted social networking websites such as Facebook and LinkedIn. Diba et al. (2019) offer further evidence on the recourse to Facebook as source of information when searching for a smuggler. However, the use of social media, and information technology more generally, varies greatly among respondents. Sanchez et al. (2018: 35) show that the use of smartphones to find information or plan onwards movements from Italy varied from 100\% among the Syrians to $27 \%$ among migrants from Ivory Coast, 29\% from Bangladesh and 32\% from Ghana (for a further discussion on the use of smartphones while travelling, we refer to Gillespie et al. 2016 and Zijlstra and Liempt 2017).

From an information-gathering perspective, it is important to highlight the interplay between online and offline interactions. This emerges clearly from the testimony of one interviewee: "I found the smuggler on Facebook and then went to his office. He was Turkish. I asked people if he was good and they said he was good, so I went with him" (interview 19). While family and friends remain an important source of information, this does not imply that the quality of such information is always superior. As pointed out by Sanchez et al. (2018: 27), "friends, acquaintances, members of the diaspora, as well as humanitarian staff often provide inaccurate or altogether mistaken information to migrants. Many interviewed migrants reported receiving bad advice from friends, relatives and community members, and on occasion regretted having followed it" (also Optimity Advisors and Seefar 2017: 23). Some of our interviewees have indeed used social media, and more generally the Internet, to complement and at times double check the information gathered through personal contacts. This points to a tendency towards an integration between online and offline. For example, price comparison between smugglers has been cited as a way in which migrants have leveraged the potential of online websites - in the same fashion as with licit products and services such as insurances policies, hotel rooms or airfares. When asked about how he could tell if what he actually paid to a smuggler was a good price, one interviewee answered: "You look on Facebook. You hear others' experiences and what is the normal price at that time" (interview 14). 


\section{Judging a Smuggler's Trustworthiness}

Once information is gathered, migrants are faced with the problem of checking the veracity of such information and then make a judgment about the trustworthiness of a given smuggler. This is a difficult task in the context of acute information asymmetry and the absence of an independent regulator. As maintained by Alpes (2012: 93) in the context of Anglophone Cameroon, trust in information is crucial in explaining "contemporary perception and practices of emigration". But which strategies can migrants rely upon to verify whether the information conveyed is accurate and the smuggler is genuinely acting in good faith? We argue that two intertwined factors play a crucial role: reputation and communities.

\section{Reputation}

As with other illegal markets (Reuter 1983, 1985), reputation is key also in human smuggling. Possessing a reputation for being reliable and competent is viewed as a vital aspect of a smuggler's identity and something that might tip the balance in favour of one smuggler rather than another (Chin 1999; Bilger et al. 2006; Spener 2009; Optimity Advisors 2015; Sanchez 2015; Campana 2018). However, cheaters and unreliable smugglers also have a strong incentive to convey misleading information or to pose as genuine and reliable. In a context in which no independent authority is available to offer guarantees and check credentials, migrants need to rely on alternative strategies. Several interviewees have indicated the key role played by the reach of one's reputation. As impostors find it costly to convey and sustain their fabricated reputation among a larger audience group, the more people mention the name of a smuggler, the more likely it is that that piece of information is correct, and that the smuggler himself is genuine and potentially reliable. This is a mechanism similar to the one employed by bona fide Mafiosi when running protection rackets, as observed by Gambetta (2019: 191-192; bona fide Mafiosi have the problem of convincing newcomers that their credentials are genuine). In the case of human smuggling, this mechanism emerges quite neatly from the words of one interviewee:

I talked to people and began to ask if they knew this smuggler. [...] I asked people and met people... I even met a second smuggler but I trusted this one [...] He got them there without problem. So I thought if these people could arrive, why cannot I? [...] I began to have trust and feel it was safe. (Interview 17).

In the same vein, another interviewee explained: "There are a lot of smugglers... good and bad, those who steal. So I got this one through the recommendation of my friends. I asked around about him and asked 3 or 4 people and they said he is good. [...] He was well-known for having good behaviour in his work". (Interview 11; also interviews 5 and 7).

Whenever possible, migrants will try to verify the credentials of a smuggler through the collection of information about the actual outcome of the journeys organised by him (interview 13; interview 17; interview 21). A reputation for being successful, perhaps not surprisingly, is a key asset for smugglers: "I heard from people that he has had success in smuggling people. [...] I spoke with a lot of people and he was able to get people to their destination in Europe through his way" (interview 11), while another interviewee maintained: "My family was doing some research about these guys and they heard that this guy takes people from Turkey to England safely and regularly" (interview 12). Another interviewee makes a similar point: "We spoke to people that we knew, people who left 
and who arrived and asked 'which smuggler did you go with? How was the behaviour of the smuggler?' In the end, there were three smugglers that had honest behaviour" (interview 15; interview 10 recalls a similar story). On the contrary, a reputation for being unsuccessful can harm the business of smuggler (interview 10). Equally, as evidenced by Kyle and Scarcelli 2009: 308) in relation to smuggling from Cuba and Haiti, a reputation for violence is also detrimental for business: "[o]ne of the primary dampers on violence by smugglers is that it's not good for repeated business".

\section{Communities}

Reputations do not travel easily (Reuter 1983, 1985), so it is not surprising that, whenever possible, migrants will approach people in their community to ask for recommendations. Such recommendations can come from cousins (interview 7), uncles (interview 13), personal friends (interview 11) and family friends (interview 12). The role of communities in circulating information about smugglers has been documented in different settings, from Ecuador (Stone-Cadena and Alvarez Velasco) to Mexico (Sanchez 2015), Afghanistan (Majidi 2018), Somalia (Majidi 2018) and Syria (Achilli 2018).

The emergence of social media and online interactions has recast the problem of checking the veracity of information in new ways. Besides physical communities of friends and people from the same village or town, there are now have virtual communities hosted on social medial platform. Exactly as offline communities, online communities can help to build and check reputations. For instance, online-based feedback is cited by migrants as a strategy to check the credentials of a given smuggler. As put it by one of our interviewees, "The most important thing is the reviews. [...] I looked for the smuggler with the best rating, with the happiest customers. I would ask people how it was and some they gave me a positive review and said the experience was good while others said be careful, don't go with him. He is bad, he laughed at me, he stole from me etc. So we had to choose who was the best smuggler" (interview 11). According to a second interviewee, "on social media you can just search and find people who had an experience with some agent and they publish it. It's like experience-sharing to help each other" (interview 14). This is confirmed by an analysis conducted by Roberts (2017) of ten Arabic-speaking Facebook groups in which smuggling services were advertised and discussed. In her work, she identified instances of both positive and negative feedback in relation to named smugglers; in some cases, smugglers even replied to the criticisms and tried to redress the situation (Roberts 2017: 40-46). Diba et al. (2019: 167) further document instances of naming-and-shaming fraudulent smugglers on Facebook: "[t]hese posts would often be very lengthy, detailing the unscrupulous smuggler's name, nationality, the country and the city they were operating in, and how they had defrauded their victim or victims, particularly regarding to payment". The same work also offers further evidence of "customer feedback" (Diba et al. 2019: 168).

For smugglers, an online presence can be a double-edge sword. On a one hand, it is an opportunity to boost their reputation and build trust. This can be done in a number of ways: for instance, smugglers may post a picture of themselves at the end of a successful trip or they may share videos received from migrants they have successfully smuggled. A particularly powerful strategy is to post screenshots of conversations-generally on WhatsApp or Telegram - a smuggler has had with his clients while they were en route to their destination. Smugglers can craft an image of themselves as reliable, careful and 
polite (Roberts 2017: 21-23; this is confirmed by Diba et al. 2019: 168). ${ }^{3}$ On the other hand, online information is difficult to control and restrict and can be easily accessed by law enforcement agencies. This is a concern explicitly expressed by one smuggler interviewed by Diba et al. (2019: 166): "I don't trust the internet so much anyway because you never know who might be watching".

However, while online platforms offer new ways to circulate information, including through a feedback mechanism, face-to-face interactions and particularly cues from a smuggler's appearance and manners still play a crucial role in shaping a migrant's judgment. A number of interviewees highlighted the continuing importance of personal contacts before a decision is made. One interviewee explained that "from his talk I was able to see that this one was a serious one [...] I felt like he was serious" (interview 10) while a second interviewee maintained: "We sat in the café and talked and he had a good demeanour" (interview 11). According to another interviewee, "I had trust after I saw the way he received me well" (interview 13). "You know that something emotionally-told us another intervieweeSometimes we see someone and are comfortable with him and you don't feel you are not comfortable with him. Someone you feel in his face that I can see the devil in your face. I spoke to some smugglers and I judged from their appearance that I was not comfortable with them". (Interview 10). Evidence from our interviewees shows that face-to-face meetings can be the make-or-break of a transaction: "I didn't have trust in him. When you go to meet him for a cup of coffee... you feel that he is lying, trying to exploit you" (interview 17). "It is important to meet face to face before deciding", told us another interviewee (interview 12).

\section{Substitutes for Trust: Guarantees, Escrow Services and Hostage-Taking}

The strategies discussed so far are designed to foster transactions by creating a sufficient level of trust between smugglers and migrants. However, there are cases where such a level of trust still fails to materialise, and therefore, alternatives to trust need to be brought in to support transactions. Based on the existing literature and the findings from our fieldwork, we believe that three strategies are particularly relevant: guarantees, third-party escrow services and the use of information as a hostage.

\section{Guarantees}

One strategy that smugglers might adopt is to offer a guarantee: if a journey is not successful, migrants will be able to repeat it at no additional cost. Akerlof (1970) has identified guarantees as a strategy that good sellers might adopt to differentiate themselves from the bad ones (as only the good sellers would be able to afford to offer such guarantees). There is evidence of such guarantees offered along a variety of smuggling routes. Stone-Cadena and Álvarez Velasco (2018) have documented it in relation to smuggling from Ecuador to Mexico and the USA; Guevara González 2018) at the Southern Mexican border and Sanchez (2015) in Mexico more generally. Aksel et al. (2015) have found evidence of such guarantees among

\footnotetext{
$\overline{3}$ An online presence can, however, be a double-edged sword for smugglers. Not only does it make them more visible to law enforcement agencies, but it can also adversely affect their reputation. Interestingly, one interviewee expressed his belief that actively seeking out "clients" on social media might indicate a lower quality of the service as smugglers who are experienced and "famous" do not have the time to manage Facebook pages (interview 10).
} 
Afghani and Pakistani migrants crossing the border between Pakistan and Iran. Offering guarantees in the form of multiple attempts was also mentioned by a number of our interviewees (interview 5; interview 12; interview 15; interview 16). Crucially, there is evidence from our fieldwork that migrants have effectively resorted to this guarantee, and that the promise of multiple attempts has been upheld by smugglers. One interviewee told us: "I paid him and I tried a few times. After one week I arrived because I have been caught by police a few times" (interview 7). Another interviewee who made three attempts to cross into Europe also maintained that he had to pay only once (interview 16). And a further interviewee recalled that:

the patrol [coastguard] came and returned us and asked us the same question. The next day they [smugglers] took us out again and the smuggler came and said to us that "since you didn't say anything about me [to the patrol] I will send you out again on the same price." (interview 17).

\section{Third-party Escrow Services}

Another strategy that smugglers may resort to is to split the payment into two parts: a deposit before departure and the remaining amount upon the successful arrival. The deposit offers a two-way guarantee: it gives assurance not only to the migrant but also to the smuggler as a non-refundable deposit commits a migrant to buy the service of that given smuggler. Research has shown that splitting the payment appears to be a widely used arrangement in human smuggling. It has been documented in relation to multiple routes, ranging from smuggling out of China (Chin 1999) to routes out of Cuba and Haiti (Kyle and Scarcelli 2009) or along the Eastern Mediterranean route (Triandafyllidou and Maroukis 2012). Our interviews have also pointed to the payment of deposits (interview 7; interview 11).

Asking for a partial payment only, however, opens up a further issue: how can a smuggler be sure that a migrant will pay the remaining amount once the journey is completed? To put it another way, it is costly - if at all possible - for, say, a Turkish-based smuggler or a Libyanbased smuggler to monitor migrants once they arrive in Italy and Greece, and a fortiori to collect the remaining sums. This is all the more true in a context where smuggling is fragmented and smugglers are directly involved in the organisation of only one part of a longer journey (Campana 2018). A solution to this problem is offered by escrow services. An escrow service is an arrangement, whereby a third party is brought in with the goal of receiving a sum of money and then eventually disbursing it when the conditions set by the seller - and agreed by the buyer - are met. Essentially, the third party will hold the funds until the transaction has reached a successful outcome, i.e. in the case of smuggling when a migrant has successfully reached the agreed destination. This system increases the confidence of migrants in choosing a given smuggler while offering to a smuggler the guarantee that the full amount is available and accessible (with conditions). This arrangement has been documented among smugglers operating between Afghanistan/Pakistan and the UK (Koser 2008) and more generally on routes to Europe across Turkey and Greece (Içduygu and Toktas 2002; Triandafyllidou and Maroukis 2012). Financial services such as hawala or Western Union can also be used to this end (Majidi 2018; Optimity Advisors 2015: 47). A considerable number of interviewees mentioned using an escrow service as part of their transaction with a smuggler (interview 3; interview 9; interview 10; interview 17; interview 27; interview 33). The system only works if both parties trust the broker (i.e. the escrow service provider). In this case, the 
smuggler borrows reputational capital from the third party. Crucially, the simplicity of this arrangement makes it very flexible and easy to set up. For example, in one case, it was a hotel owner who was identified as trustworthy by a migrant who was an escrow service provider (interview 15).

\section{Information as a Hostage}

Migrants appear to have pro-actively developed strategies to hold smugglers to their promises. One such strategy is known in cooperation theory as "hostage-taking" (Schelling 1960 and 2006; Cook et al. 2005; Schelling 2006; Campana and Varese 2013). In this case, it is the compromising information about the smuggler's activity that is held hostage (without the need for any physical hostage). The use of hostage-taking as a strategy to guarantee promises (Raub 2004) is a practice that has a long and well-documented history. For instance, Ancient Romans started resorting to it as early as the end of the Second Punic War in 202 BC (Allen 2006: 10). The use of non-physical goods, such as compromising information, has been documented in a number of illegal settings from paedophile rings to criminal organisations (Gambetta 2009; Campana and Varese 2013). The (successful) use of this strategy in the context of human smuggling clearly emerges from the testimony below:

We had the number of the smuggler and called him and told him this happened with us and the boat was broken and we did not tell the police about you and because of that we want a new trip or we will return to the police. You are this person and one of the men said that "I have a photo of you. I took a photo of you. Believe me I will publish the photo if you don't bring us another boat and we also have children and women with us so behave with us" and he [the smuggler] said "okay, okay, tomorrow I will get you a new boat and will send you on a new trip." (interview 17).

The same interviewee appears to have resorted to a similar mechanism more than once during the journey:

So I went back and talked to the smuggler about what had happened and said "Look I didn't tell them about you. They were searching and asking "from where did you get the passport, give us the name of the person from whom you received the passport". If I wanted to ruin your life, I could have given them your name. Your picture is with me..." I had learned this from the man in Turkey. "Also the photo of the girl who went with me to the airport is with me and her phone number. And the house where people wait to be smuggled before their plane comes..." (interview 17).

This is a strategy that has not received much attention in the literature on human smuggling; yet, it is indicative of a more nuanced picture than the binary "predator-victim" perspective.

\section{Conclusions}

Choosing a smuggler is a very difficult task as it may lead to severe adverse consequences. These could range from being cheated to being subject to abuse up to the loss of one's own life. In this paper, we studied how migrants faced with different courses of action when choosing a smuggler make a decision to pick the one that is likely to have the best overall outcome - under very difficult conditions. More specifically, we explored both the challenges 
related to transacting in the context of human smuggling and the strategies developed to overcome these challenges.

We maintained that the choice of a smuggler is normally taken under a number of challenging conditions. Firstly, illegality, which in turn leads to the absence of formal enforcement mechanisms to solve disputes, ensures compliance and enforce contracts. Furthermore, illegality hinders the availability and quality of the information available (Reuter 1983 and 1985; Campana and Varese 2013). Secondly, there exists severe information asymmetry between migrants and smugglers (Bilger et al. 2006; Campana and Varese 2013) and, further, a context of low generalised trust. Yet, successful transactions between smugglers and migrants $d o$ take place regularly around the World. Theoretically, this poses an interesting conundrum similar to one explored by George Akerlof (1970) in his seminal study of the second-hand car market (Bilger et al. 2006). What strategies are employed to address such conundrum?

Information plays a crucial role in a migrant's decision-making. Gathering information about smugglers is the first key step. This is done through personal contacts as well as online social media. While the former is still prevalent, social media have an increasing prominence. Crucially, the two main sources are not mutually exclusive, but we observed a tendency towards an integration between online and offline. While, for instance, migrants might use the Internet to find a smuggler or compare prices, they will nonetheless arrange a face-to-face meeting and evaluate physical cues, i.e. appearance and manners, before making their final decision.

When judging the veracity of the information collected, we highlighted the role played by (a) reputation and (b) communities. As is also the case in other illegal markets (Reuter 1983), reputation plays a crucial role. But how can a reputation be checked? We maintained that the reach of a smuggler's reputation is taken as a sign of a smuggler's bona fide intentions and reliability. The more people mention the name of a smuggler (in a positive light), the more likely it is that that piece of information is reliable. In addition, migrants also try to collect information about the actual outcomes of journeys to assess the credentials of smugglers. As reputations do not travel easily, local communities still play a crucial role in checking information about smugglers. Yet, they are now being supplemented by virtual communities on social media: spaces in which migrants can gather information from beyond the immediate physical circle and/or close friends and family members. Crucially, they can also check that information through online feedback, comments and contacts with other migrants. Smugglers themselves may also rely on pro-active strategies to build a positive reputation in virtual communities.

However, it might not always be possible to generate sufficient trust between individual smugglers and migrants for a transaction to materialise. As a solution, both parties have developed additional strategies to foster transactions. We discussed three such strategies in detail: guarantees, third-party escrow services and the use of information as a hostage. For instance, as a guarantee, migrants are promised multiple attempts at no extra cost if the first journey is unsuccessful. Another strategy is to split the payment into two parts and bring in a third-party escrow service to assure the migrant about the bona fide character of the smuggler. Finally, migrants may use compromising information on the smuggler as a so-called hostage-taking strategy to ensure that the latter maintains his commitments - in a similar fashion to what has been observed in other contexts outside the reach of the law such as paedophile rings, corruption rings and criminal groups (Gambetta 2009; Campana and Varese 2013). 
This paper has pointed to a broad policy implication, namely the need to move away from a simplistic predator-victim discourse - in line with Zhang, Sanchez and Achilli (2018). Interactions underpinning the smuggling market are more complex and nuanced - and in many ways similar to those taking place in other markets, both legal and illegal, that are characterised by similar features (e.g. generalised low trust, information asymmetries, difficulties in checking credentials and reputations). Secondly, this paper has shown that migrants do possess agency: they collect information and make decisions. This confirms the analytic distinction between human trafficking and smuggling (Campana and Varese 2016; Kleemans 2011). This is not to say that migrant journeys are without risk, nor that the relationship between migrants and smugglers is symmetrical — quite the opposite, as documented cases of abuse and death suffered by migrants remind us.

Acknowledgments We are grateful to the editor and two anonymous referees for their helpful comments. We are extremely grateful to Karin Bashir and Alkisti Alevropoulou-Malli for their fieldwork assistance and to Zoe Roberts for her assistance with coding: they all worked with great passion and accuracy. We are most thankful to our interviewees who have been very generous with their time often during difficult circumstances.

Funding Information This work was supported by a grant from the Cambridge Humanities Research Grants Scheme, University of Cambridge, which we gratefully acknowledge.

\section{Compliance with Ethical Standards}

Conflict of Interest The authors declare that they have no conflict of interest.

Open Access This article is licensed under a Creative Commons Attribution 4.0 International License, which permits use, sharing, adaptation, distribution and reproduction in any medium or format, as long as you give appropriate credit to the original author(s) and the source, provide a link to the Creative Commons licence, and indicate if changes were made. The images or other third party material in this article are included in the article's Creative Commons licence, unless indicated otherwise in a credit line to the material. If material is not included in the article's Creative Commons licence and your intended use is not permitted by statutory regulation or exceeds the permitted use, you will need to obtain permission directly from the copyright holder. To view a copy of this licence, visit http://creativecommons.org/licenses/by/4.0/.

\section{References}

Achilli, L. (2018). The 'good' smuggler: the ethics and morals of human smuggling among Syrians. The Annals of the American Academy of Political and Social Sciences, 676(1), 77-96.

Advisors, O. (2015). A study on smuggling of migrants. Final report. Brussels: European Commission.

Advisors, O., \& Seefar. (2017). How West African migrants engage with migration information en-route to Europe. Brussels: European Commission.

Akerlof, G. A. (1970). The market for 'lemons': quality uncertainty and the market mechanism. The Quarterly Journal of Economics, 84(3), 488-500.

Aksel, D. B., Dimitriadi, A., Hendow, M., İçduygu, A., Karacay, A. B., Maroufof, M., \& Andersson-Pucher, J. (2015). Study on smuggling of migrants: characteristics, responses and cooperation with third countries. Case study 3: Pakistan-Turkey-Greece. Brussels: European Commission.

Allen, J. (2006). Hostages and hostage-taking in the Roman Empire. New York: Cambridge University Press.

Alpes, M. J. (2012). Bushfalling at all cost: the economy of migratory knowledge in anglophone Cameroon. African Diaspora. African Diaspora, 5(1), 90-115.

Antonopoulos, G. A., \& Winterdyk, J. (2006). The smuggling of migrants in Greece: an examination of its social organization. European Journal of Criminology, 3(4), 439-461. 
Ayalew Mengiste, T. (2018). Refugee protections from below: smuggling in the Eritrea-Ethiopia context. The Annals of the American Academy of Political and Social Sciences, 676(1), 57-76.

Bilger, V., Hofmann, M., \& Jandl, M. (2006). Human smuggling as a transnational service industry: evidence from Austria. International Migration, 44(4), 59-93.

Campana, P. (2017). The market for human smuggling into Europe: a macro perspective. Policing, 11(4), 448456.

Campana, P. (2018). Out of Africa: the organization of migrant smuggling across the Mediterranean. European Journal of Criminology, online first. https://doi.org/10.1177/1477370817749179.

Campana, P. (2020). Human smuggling: structure and mechanisms. Crime and Justice, 49, 1, online first. https://doi.org/10.1086/708663.

Campana, P., \& Varese, F. (2013). Cooperation in criminal organizations: kinship and violence as credible commitments. Rationality and Society, 25(3), 263-289.

Campana, P., \& Varese, F. (2016). Exploitation in human trafficking and smuggling. European Journal on Criminal Policy and Research, 22(1), 89-105.

Chin, K.-L. (1999). Smuggled Chinese: clandestine immigration to the United States. Philadelphia: Temple University Press.

Coleman, J. S. (1990). Foundations of social theory. Cambridge: Harvard University Press.

Cook, K. S., Hardin, R., \& Levi, M. (2005). Cooperation without trust? New York: Russell Sage Foundation.

Dekker R., Engbersen G., Klaver J and Vonk H. (2018). Smart refugees: how Syrian asylum migrants use social media information in migration decision-making. Social Media + Society, 1-11.

DHS. (2019). Border security metrics report. Fiscal year 2018. Washington: Department of Homeland Security.

Diba, P., Papanicolaou, G., \& Antonopoulos, G. A. (2019). The digital routes of human smuggling? Evidence from the UK. Crime prevention and community safety, 21(2), 159-175.

Doomernik, J., \& Kyle, D. (2004). Organized migrant smuggling and state control: conceptual and policy challenges. Special issue of Journal of International Migration and Integration, 5(3), 93-102.

Elster, J. (1989). Nuts and bolts for the social sciences. Cambridge University Press.

Frontex. (2017). Risk analysis for 2017. Warsaw: European Border and Coast Guard Agency.

Frontex. (2019). Risk analysis for 2019. Warsaw: European Border and Coast Guard Agency.

Gambetta, D. (Ed.). (1988). Trust. Making and breaking cooperative relations. Oxford: Basil Blackwell.

Gambetta, D. (2009). Codes of the underworld: how criminals communicate. Princeton: Princeton University Press.

Gillespie, M., Ampofo, L., Cheesman, M., Faith, B., Iliadou, E., Issa, A., Osseiran, S., Skleparis, D. (2016). Mapping refugee media journeys: Smartphones and social media networks. Project Report: The Open University and France Médias Monde.

Guevara González, Y. (2018). Navigating with coyotes: pathways of central American migrants in Mexico's southern borders. The Annals of the American Academy of Political and Social Sciences, 676(1), 174-193.

Hales, L., \& Gelsthorpe, L. (2012). The criminalisation of migrant women. ESRC final report. Cambridge: Institute of Criminology Cambridge University.

Hardin, R. (2006). Trust. Oxford: Polity.

Herman, E. (2006). Migration as a family business: the role of personal networks in the mobility phase of migration. International Migration, 44(4), 191-230.

Içduygu, A., \& Toktas, S. (2002). How do smuggling and trafficking operate via irregular border crossings in the Middle East? Evidence from fieldwork in Turkey. International Migration, 40(6), 25-54.

Kleemans, E. R. (2011). Human smuggling and human trafficking. In M. Tonry (Ed.), Oxford handbook on crime and public policy (pp. 409-427). New York: Oxford University Press.

Koser, K. (2008). Why migrant smuggling pays. International Migration, 46(2), 3-26.

Krippendorff, K. (2004). Content analysis. Thousand Oaks: Sage.

Kyle, D., \& Scarcelli, M. (2009). Migrant smuggling and the violence question: evolving illicit migration markets for Cuban and Haitian refugees. Crime Law Soc Change, 52(3), 297-311.

Maher, S. (2018). Out of West Africa: human smuggling as a social enterprise. The Annals of the American Academy of Political and Social Sciences, 676(1), 36-56.

Majidi, N. (2018). Community dimensions of smuggling: the case of Afghanistan and Somalia. The Annals of the American Academy of Political and Social Sciences, 676(1), 97-113.

Massey, D. S., Durand, J., \& Pren, K. A. (2016). Why border enforcement backfired. American Journal of Sociology, 121(5), 1557-1600.

McCarthy, B., Hagan, J., \& Cohen, L. E. (1998). Uncertainty, cooperation, and crime: understanding the decision to co-offend. Social Forces, 77(1), 155-184.

Raub, W. (2004). Hostage posting as a mechanism of trust: binding, compensation and signaling. Rationality and Society, 16(3), 319-365.

Reuter, P. (1983). Disorganised crime: the economics of the visible hand. Cambridge: MIT Press. 
Reuter, P. (1985). The organization of illegal markets: an economic analysis. Washington: National Institute for Justice.

Robinson, V., \& Segrott, J. (2002). Understanding the decision-making of asylum seekers (p. 243). London: Home Office Research Study.

Roberts, Zoe. (2017). Information Exchange between Smugglers and Migrants: An Analysis of Online Interactions in Facebook Groups. MPhil dissertation, Institute of Criminology, University of Cambridge.

Sanchez, G. E. (2015). Human smuggling and border crossing. Abingdon and New York: Routledge.

Sanchez, G. (2018a). Portrait of a human smuggler: race, class and gender among facilitators of irregular migration on the U.S.-Mexico border. In M. Bosworth, A. Parmar, \& Y. Vazquez (Eds.), Race, criminal justice and migration control: enforcing the boundaries of belonging (pp. 29-42). Oxford: Oxford University Press.

Sanchez, G. (2018b). Mexico. In Triandafyllidou, A. and M.L. McAuliffe (eds.), Migrant smuggling data and research: a global review of the emerging evidence base, volume 2. IOM: Geneva IOM V2, 143-166.

Sanchez, E. G., \& Zhang, S. X. (2018). Rumors, encounters, collaborations, and survival: the migrant smugglingdrug trafficking Nexus in the U.S. southwest. The Annals of the American Academy of Political and Social Sciences, 676(1), 135-151.

Sanchez, G., Hoxhaj, R., Nardin, S., Geddes, A., Achilli, L., \& Sona Kalantaryan, R. (2018). A study of the communication channels used by migrants and asylum seekers in Italy, with a particular focus on online and social media. Brussels: European Commission.

Schelling, T. (1960). The strategy of conflict. Cambridge: Harvard University Press.

Schelling, T. (2006). Strategies of commitments and other essays. Cambridge, MA: Harvard University Press.

Siegel, D. (2019). Human smuggling reconsidered: the case of Lesbos. In P. C. van Duyne, A. Serdyuk, G. A. Antonopoulos, J. H. Harvey, \& K. von Lampe (Eds.), Constructing and organising crime in Europe (pp. 103-121). The Hague: Eleven International Publishing.

Slack, J., \& Martínez, E. D. (2018). What makes a good human smuggler? The difference between satisfaction with and recommendation of coyotes on the U.S.-Mexico border. The Annals of the American Academy of Political and Social Sciences, 676(1), 152-173.

Spener, D. (2004). Mexican migrant-smuggling: a cross-border cottage industry. Journal of International Migration and Integration/Revue de l'integration et de la migration international, 5(3), 295-320.

Spener, D. (2009). Clandestine crossings: migrants and coyotes on the Texas-Mexico border. New York: Cornell University Press.

Stone-Cadena, V., \& Álvarez Velasco, S. (2018). Historicizing mobility: coyoterismo in the indigenous Ecuadorian migration industry. The Annals of the American Academy of Political and Social Sciences, 676(1), 194-211.

Triandafyllidou, A., \& Maroukis, T. (2012). Migrant smuggling: irregular migration from Asia and Africa to Europe. Basingstoke: Palgrave Macmillan.

UN 2000. Protocol against the Smuggling of Migrants by Land, Sea, and Air, supplementing the United Nations Convention against Transnational Organized Crime. Available at: https://treaties.un.org/pages/ViewDetails. aspx?src=TREATY\&mtdsg_no=XVIII-12-b\&chapter=18.

Van Liempt, I., \& Doomernik, J. (2006). Migrant's agency in the smuggling process: the perspectives of smuggled migrants in the Netherlands. International Migration, 44(4), 165-190.

Yamagishi, T., \& Yamagishi, M. (1994). Trust and commitment in the United States and Japan. Motivation and Emotion, 18(2), 129-166.

Yildiz, A. (2017). Perception of 'smuggling business' and decision making processes of migrants. Ankara: International Organization for Migration.

Zhang, S. X. (2007). Smuggling and trafficking in human beings: All roads lead to America. Westport, CT: Praeger/Greenwood

Zhang, S. X., \& Chin, K.-1. (2002). Enter the dragon: inside Chinese human smuggling organisations. Criminology, 40(4), 737-768.

Zhang, S. X., Sanchez, G. E., \& Achilli, L. (2018). Crimes of solidarity in mobility: alternative views on migrant smuggling. The Annals of the American Academy of Political and Social Science, 676(1), 6-15.

Zijlstra, J., \& Liempt, I. V. (2017). Smart (phone) travelling: understanding the use and impact of mobile technology on irregular migration journeys. International Journal of Migration and Border Studies, 3(2-3), $174-191$.

Publisher's Note Springer Nature remains neutral with regard to jurisdictional claims in published maps and institutional affiliations. 